\title{
Three distinct cutaneous malignancies arising in a post-burn scar
}

\section{Trzy różne nowotwory złośliwe skóry na podłożu blizny pooparzeniowej}

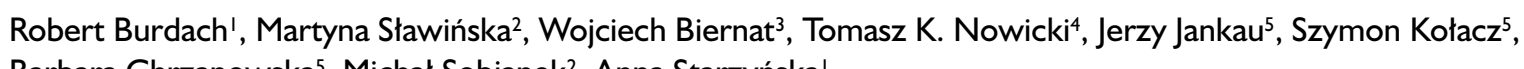
Barbara Chrzanowska ${ }^{5}$, Michał Sobjanek², Anna Starzyńska'

\author{
'Department of Oral Surgery, Medical University of Gdańsk, Poland \\ 2Department of Dermatology, Venereology and Allergology, Medical University of Gdańsk, Poland \\ ${ }^{3}$ Department of Pathomorphology, Medical University of Gdańsk, Poland \\ ${ }^{4} 2^{\text {nd }}$ Department of Radiology, Medical University of Gdańsk, Poland \\ ${ }^{5}$ Department of Plastic Surgery, Medical University of Gdańsk, Poland \\ 'Zakład Chirurgii Stomatologicznej Gdańskiego Uniwersytetu Medycznego, Polska \\ 2Katedra i Klinika Dermatologii, Wenerologii i Alergologii Gdańskiego Uniwersytetu Medycznego, Polska \\ ${ }^{3}$ Katedra i Zakład Patomorfologii Gdańskiego Uniwersytetu Medycznego, Polska \\ ${ }^{4}$ II Zakład Radiologii Gdańskiego Uniwersytetu Medycznego, Polska \\ ${ }^{5}$ Katedra i Klinika Chirurgii Plastycznej Gdańskiego Uniwersytetu Medycznego, Polska
}

Dermatol Rev/Przegl Dermatol 2019, 106, 417-423

DOI: https://doi.org/10.5। |4/dr.2019.88260

\section{CORRESPONDING AUTHOR/} ADRES DO KORESPONDENCJI: dr n. med. Martyna Sławińska Katedra i Klinika Dermatologii, Wenerologii i Alergologii Gdański Uniwersytet Medyczny ul. Smoluchowskiego 17

80-214 Gdańsk

tel.: +48585844014

e-mail: mslawinska@gumed.edu.pl

\begin{abstract}
Introduction. Prior clinical observations suggest an increased risk of carcinogenesis within a post-burn scar. The most common type of a neoplasm observed in such cases is squamous cell carcinoma, followed by basal cell carcinoma, melanoma, and sarcomas. Cases of coexistence of different neoplasms developing within one burn scar have rarely been reported in international literature.
\end{abstract}

Objective. To present a patient affected by three independent skin neoplasms that developed within a post-burn scar.

Case report. A 77-year-old man, who sustained an extensive burn of the head and upper extremities in childhood, was admitted to the Department of Dermatology to undergo a diagnostic examination of two scalp skin tumours developing within the post-burn scar. Three months earlier right cheek melanoma was excised. The histopathological examination confirmed the diagnosis of squamous cell carcinoma and basosquamous carcinoma.

Conclusions. This case may confirm the carcinogenicity of burn scars, and indicates the necessity of long-term monitoring of patients with such lesions.

\section{STRESZCZENIE}

Wprowadzenie. Obserwacje kliniczne wskazują na podwyższone ryzyko rozwoju nowotworów skóry w obrębie blizn pooparzeniowych. Najczęstszym nowotworem skóry rozwijającym się w obrębie blizn pooparzeniowych jest rak kolczystokomórkowy skóry, natomiast rzadziej obserwuje się raka podstawnokomórkowego skóry, czerniaka, mięsaki. W piśmiennictwie opisano dotąd jedynie nieliczne przypadki współistnienia ze sobą różnych nowotworów skóry w obrębie jednej blizny pooparzeniowej.

Cel pracy. Przedstawienie przypadku pacjenta, u którego w obrębie blizny pooparzeniowej wystąpiły trzy niezależne nowotwory skóry. 
Opis przypadku. Mężczyznę 77-letniego, który w dzieciństwie doznał rozległego oparzenia skóry głowy i kończyn górnych, przyjęto do kliniki w celu diagnostyki dwóch guzów owłosionej skóry głowy rozwijających się w bliźnie pooparzeniowej. Trzy miesiące wcześniej u pacjenta przeprowadzono resekcję czerniaka skóry policzka prawego. $\mathrm{W}$ badaniu histopatologicznym wycinków guzów skóry skalpu stwierdzono utkanie raka kolczystokomórkowego oraz raka podstawnokolczystokomórkowego skóry.

Wnioski. Wydaje się, że przedstawiony przypadek potwierdza onkogenny potencjał blizn pooparzeniowych oraz wskazuje na konieczność wieloletniego monitorowania tej grupy pacjentów.

Key words: melanoma, squamous cell carcinoma, burn scar, post-burn scar, basosquamous cell carcinoma.

Słowa kluczowe: czerniak, rak kolczystokomórkowy skóry, blizna pooparzeniowa, rak podstawnokolczystokomórkowy skóry.

\section{INTRODUCTION}

At the beginning of the $20^{\text {th }}$ century first cases of skin squamous cell carcinoma (SCC) within postburn scars were described. Subsequent clinical observations provided an evidence that extent post-burn scars predispose to development of skin cancers. Currently, such lesions are counted among classic preneoplastic conditions. The term Marjolin's ulcer (tumour) used to describe neoplasms that emerged due to chronic inflammatory skin conditions of diverse aetiology. Squamous cell carcinoma is the most common neoplasm developing within post-burn scars. There are only a few reports that document the development of various skin cancers within post-burn scars in one patient, hence, the authors thought it was important to present this case.

\section{OBJECTIVE}

To present a patient affected by three independent skin neoplasms that developed within a post-burn scar.

\section{CASE REPORT}

A 77-year-old man was admitted to the Department of Dermatology in order to undergo a diagnostic examination of two scalp skin tumours that had developed within the post-burn scar (fig. 1). At the age of 5 the patient experienced an extensive thermal trauma involving the scalp and upper extremities during the Second World War. Three months before being admitted to Dermatology Clinic, the patient had a right cheek skin neoplasm excised - histopatho-

\section{WPROWADZENIE}

Na początku XX wieku opisano pierwsze przypadki rozwoju raka kolczystokomórkowego skóry (squamous cell carcinoma - SCC) w obrębie blizn pooparzeniowych. Późniejsze obserwacje kliniczne dostarczyły dowodów, że rozległe blizny pooparzeniowe predysponują do rozwoju nowotworów skóry. Obecnie zmiany te zalicza się do klasycznych stanów przednowotworowych. Terminem owrzodzenie (guz) Marjolina zwykło się określać nowotwór powstały na podłożu przewlekłych stanów zapalnych skóry o różnej etiologii. Najczęstszym nowotworem rozwijającym się w obrębie blizn pooparzeniowych jest SCC. W nielicznych doniesieniach opisano rozwój kilku różnych nowotworów skóry w obrębie blizn pooparzeniowych $\mathrm{u}$ jednego pacjenta, dlatego autorzy uznali za celowe przedstawienie tego przypadku.

\section{CEL PRACY}

Przedstawienie przypadku pacjenta, u którego w obrębie blizny pooparzeniowej wystąpiły trzy niezależne nowotwory skóry.

\section{OPIS PRZYPADKU}

Mężczyznę 77-letniego przyjęto do Kliniki Dermatologii w celu diagnostyki dwóch guzów owłosionej skóry głowy, które pojawiły się w obrębie blizny pooparzeniowej (ryc. 1). Pacjent w wieku 5 lat doznał rozległego urazu termicznego obejmującego skórę głowy i kończyn górnych w przebiegu działań wojennych w czasie II wojny światowej. Trzy miesiące przed przyjęciem do Kliniki Derma- 


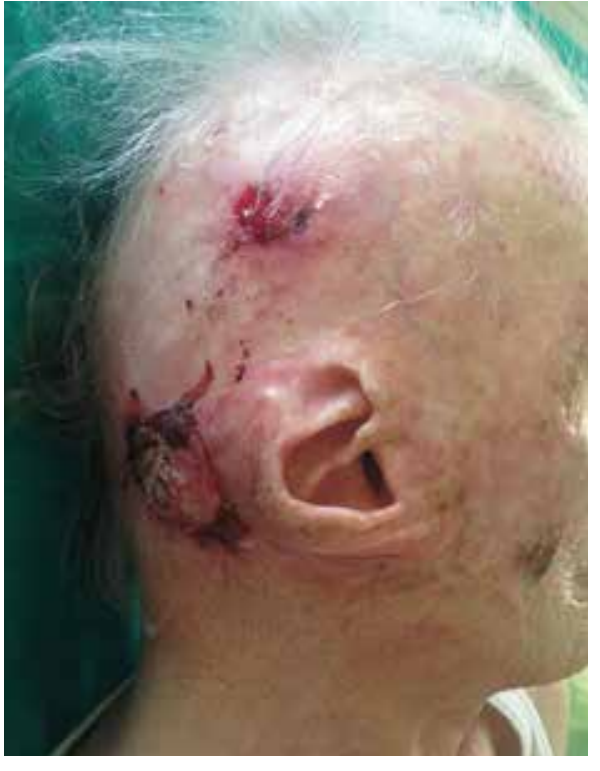

Figure I. Clinical presentation: an ulceration in the parietal region of the scalp (basosquamous carcinoma), an ulcerated tumour in the right retroauricular region (squamous cell carcinoma) and granulation tissue in the scar after right cheek melanoma primary excision

Rycina I. Obraz kliniczny: owrzodzenie okolicy ciemieniowej (rak podstawnokolczystokomórkowy), owrzodziały guz okolicy zausznej prawej (rak kolczystokomórkowy) oraz ziarninujące tkanki w bliźnie po pierwotnym wycięciu czerniaka skóry policzka prawego
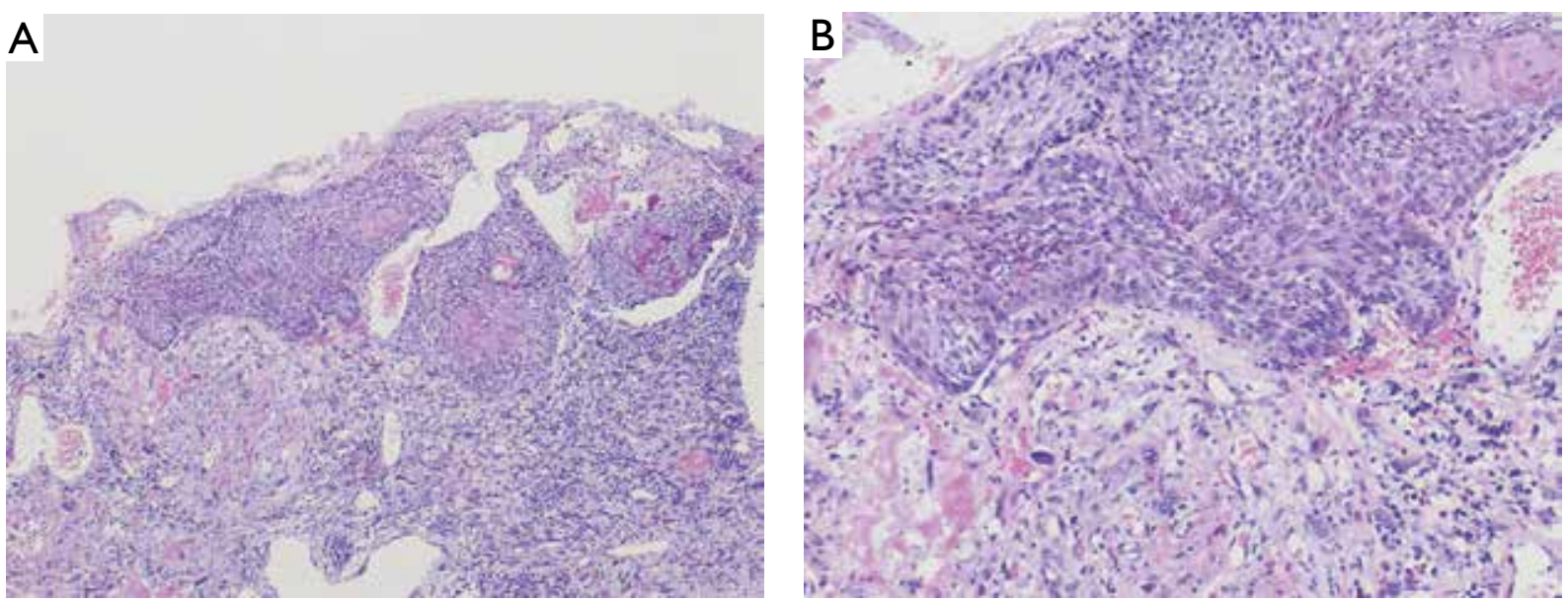

Figure 2. Carcinoma showing basaloid differentiation and focal squamous cornification (A), and infiltrative component with squamoid maturation (B)

Rycina 2. Nowotwór o zróżnicowaniu bazaloidalnym z obecnością ognisk rogowacenia $(A)$ i komponentem inwazyjnym o różnicowaniu kolczystokomórkowym (B)
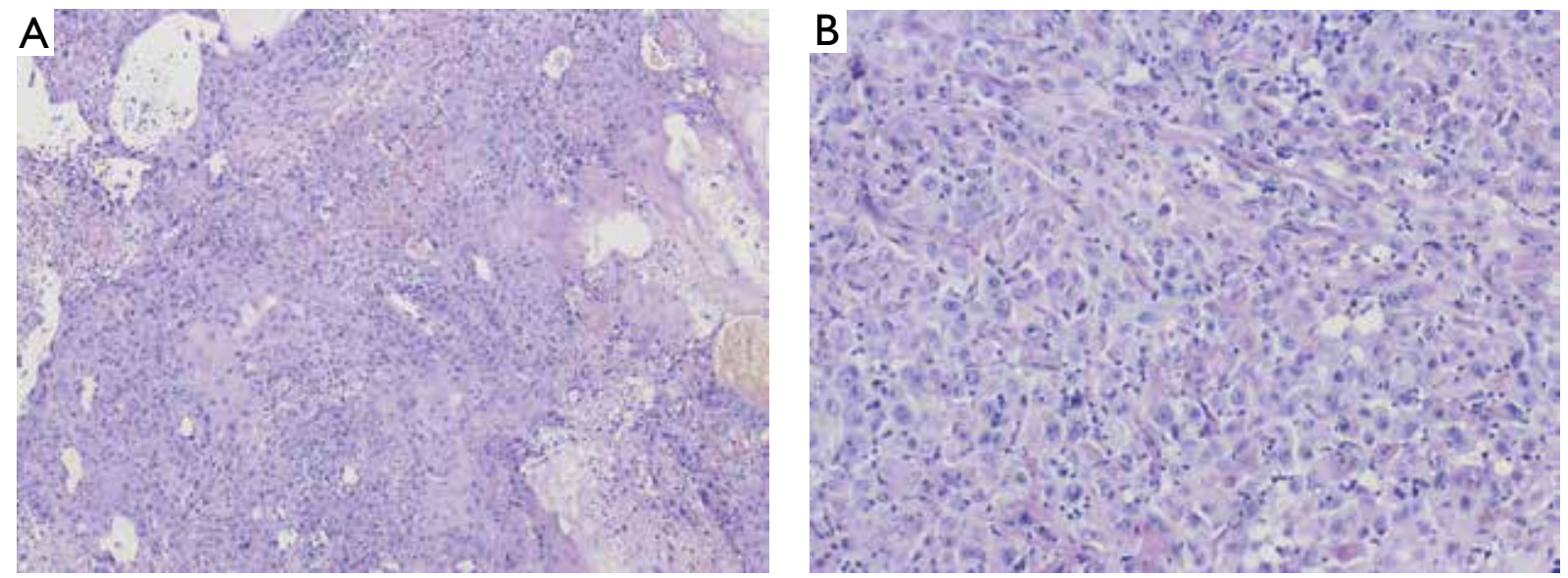

Figure 3. Poorly differentiated squamous cell carcinoma shows more distinct differentiation at the superficial portion (A), and solid infiltrative component in the deeper portion of the tumor (B)

Rycina 3. Niskozróżnicowany rak kolczystokomórkowy skóry wykazujący bardziej zaznaczone różnicowanie w części powierzchownej (A) oraz obecność głębiej umiejscowionego litego komponentu naciekającego (B) 


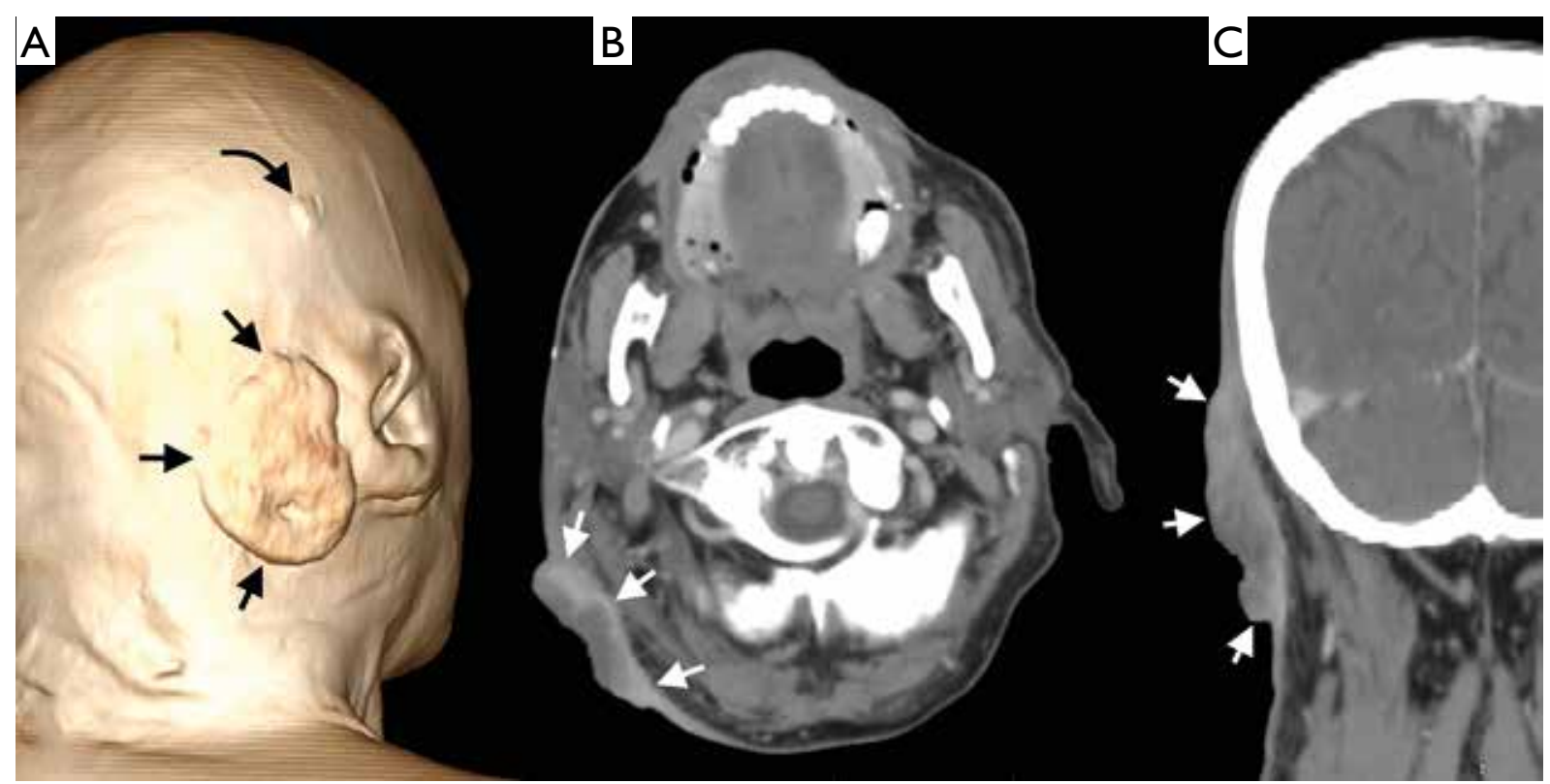

Figure 4. Contrast-enhanced computed tomography. A - two lesions in the parietal region (curved arrow) and in the retroauricular region (straight arrows), $\mathbf{B}$ - on the transverse plane in contrast-enhanced examination the lesion is visible in the retroauricular region (white arrows), $\mathbf{C}$ - the same lesion is visible in the coronal plane (white arrows)

Rycina 4. Badanie metodą tomografii komputerowej z kontrastem. A - rekonstrukcja objętościowa z widocznymi dwoma zmianami w okolicy ciemieniowej (zakrzywiona strzałka) i zausznej (proste strzałki), B - naciek w okolicy zausznej (białe strzałki) widoczny na przekroju poprzecznym w badaniu po kontraście, C - ten sam naciek widoczny w płaszczyźnie czołowej (białe strzałki)

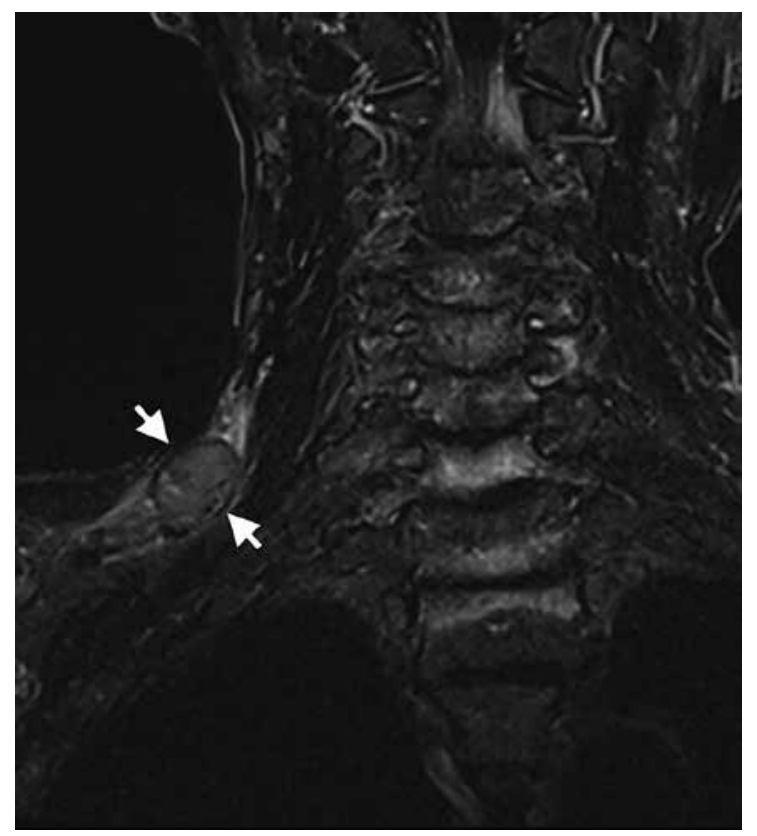

Figure 5. Magnetic resonance examination in T2-weighted image with fat saturation (Turbo Inversion Recovery with Magnitude sequence) in the coronal plane at the level of cervical vertebral bodies. White arrows show an enlarged pathological lymph node at the VA level surrounded by hyperintense (bright) oedema

Rycina 5. Badanie metodą rezonansu magnetycznego w obrazach T2-zależnych z saturacją tkanki tłuszczowej (sekwencja Turbo Inversion Recovery with Magnitude) w płaszczyźnie czołowej na wysokości trzonów kręgów szyjnych. Białe strzałki wskazują powiększony, patologiczny węzeł chłonny z grupy VA z towarzyszącym hiperintensywnym (jasnym) obrzękiem w otoczeniu tologii, w innym ośrodku, wykonano resekcję guza skóry policzka prawego - w badaniu histopatologicznym wykazano utkanie czerniaka (inwazja skóry właściwej na głębokość $6,5 \mathrm{~mm}$, bez zajęcia naczyń i odczynu limfocytarnego $\mathrm{w}$ dnie, indeks mitotyczny $-25 / \mathrm{mm}^{2}$ ). W badaniu metodac pozytonowej tomografii emisyjnej (positron emission tomography - PET) stwierdzono wówczas zmianę w obrębie skóry okolicy potylicznej prawej o metabolizmie procesu rozrostowego; poza tym nie stwierdzono cech rozsiewu nowotworu. Margines resekcji poszerzono, nie wykonano badania węzła wartownika. Podczas hospitalizacji w Klinice Dermatologii pobrano wycinki do badania histopatologicznego z ziarninującej tkanki w bliźnie po wycięciu czerniaka (fragment skóry z owrzodzeniem i bliznowaceniem), owrzodzenia skóry okolicy ciemieniowej (rak podstawnokolczystokomórkowy skóry; ryc. 2) oraz guza skóry okolicy zausznej prawej (rak kolczystokomórkowy skóry, G3; ryc. 3).

Pacjenta przekazano do Kliniki Chirurgii Plastycznej w celu dalszego leczenia chirurgicznego. $\mathrm{W}$ przedoperacyjnym badaniu metodą tomografii komputerowej głowy i szyi z kontrastem stwierdzono masywny naciek tkanek miękkich grubości do $17 \mathrm{~mm}$ okolicy zausznej oraz małżowiny usznej prawej na odcinku ok. $9 \mathrm{~cm} \mathrm{w}$ wymiarze przednio-tylnym i do $6 \mathrm{~cm} \mathrm{w}$ wymiarze kranialno-kaudalnym, z silnym wzmocnieniem pokontrastowym; 
logical examination revealed melanoma (dermis invasion down to $6.5 \mathrm{~mm}$; no vessel involvements and lymphocytic reaction in the bottom; mitotic index $-25 / \mathrm{mm}^{2}$ ). Positron emission tomography (PET) imagining confirmed a lesion within the skin of the right occipital region that exhibited proliferative metabolism; otherwise, there were no signs of neoplastic spread. Resection margin was enlarged; sentinel lymph note (SLN) biopsy was not performed. During hospitalization at the Department of Dermatology, the samples for histopathological examination were taken from: granulomatous tissue present within the scar post melanoma excision (a skin section with ulceration and cicatrisation), skin ulceration of the parietal region (basosquamous cell carcinoma; fig. 2), and skin tumour of the right postauricular region (squamous cell carcinoma, G3; fig. 3).

The patient was transferred to Department of Plastic Surgery for further surgical treatment. Preoperative head and neck computed tomography scan with contrast medium revealed a massive infiltration of soft tissues with the thickness of up to $17 \mathrm{~mm}$ in the postauricular region and the right auricle at the section of about $9 \mathrm{~cm}$ in the anteroposterior dimension and up to $6 \mathrm{~cm}$ in the craniocaudal dimension, with a strong post-contrast enhancement; similarly, smaller lesions were visible in the right parietal region (fig. 4). The scan did not show signs of osseous destruction. Magnetic resonance imaging revealed an enlarged lymph node in the VB group on the right sized $25 \times 18 \mathrm{~mm}$ (fig. 5).

In general anaesthesia, neoplasms found in the postauricular and parietal regions were excised, the postoperative defect was reconstructed with the use of dermal-galeal flap rotated from the occipital region. Moreover, having removed the melanoma, granulomatous tissues of the scar area were excised and the created defect was dressed with a skin graft.

Fine-needle aspiration biopsy of the suspicious lymph node confirmed squamous cell carcinoma metastases, and therefore, it was decided to perform a selective nodal surgery on the right side of the neck (II-V levels). In one of the removed lymph nodes, a metastasis of SCC was confirmed that did not go beyond the capsule (immunophenotype: CKAE1/AE3+, p63+, S100-, HMB45-, Melan A-, CD10-). A two-year observation revealed neither further nodal metastases nor metastases to distant organs.

\section{DISCUSSION}

Pathomechanism of neoplastic transformation within post-burn scars is not known. There is no doubt that the duration of chronic inflammation in post-burn wounds that heal per secundam is of importance. Moreover, the influence of the following is tak- podobne, mniejsze zmiany były widoczne w okolicy ciemieniowej prawej (ryc. 4). Nie stwierdzono cech destrukcji kostnej. Badaniem metodą rezonansu magnetycznego wykazano powiększony węzeł chłonny w grupie VB po stronie prawej o wymiarach $25 \times 18 \mathrm{~mm}$ (ryc. 5).

W znieczuleniu ogólnym wycięto nowotwory zlokalizowane w okolicy zausznej i ciemieniowej, a powstały ubytek poddano rekonstrukcji z wykorzystaniem płata skórno-czepcowego zrotowanego z okolicy potylicznej. Wycięto również ziarninujące tkanki okolicy blizny po wcześniej usuniętym czerniaku, zaopatrując powstały ubytek przeszczepem skóry.

W biopsji aspiracyjnej cienkoigłowej podejrzanego węzła chłonnego stwierdzono przerzut raka płaskonabłonkowego, w związku z czym zdecydowano o wykonaniu selektywnej operacji węzłowej na szyi po stronie prawej (poziomy II-V). W jednym z usuniętych węzłów chłonnych stwierdzono przerzut raka płaskonabłonkowego, nieprzekraczający torebki węzła (o immunofenotypie: CKAE1/ AE3+, p63+, S100-, HMB45-, Melan A-, CD10-). W czasie dwuletniej obserwacji nie odnotowano kolejnych przerzutów węzłowych ani też odległych przerzutów narządowych.

\section{OMÓWIENIE}

Patomechanizm transformacji nowotworowej w obrębie blizn pooparzeniowych nie jest znany. Niewątpliwie istotny jest czas utrzymywania się przewlekłego stanu zapalnego $\mathrm{w}$ ranach pooparzeniowych gojacych się per secundam. Ponadto pod uwagę bierze się wpływ toksyn, kokancerogenów, upośledzonego krążenia miejscowego oraz odpowiedzi immunologicznej, a także udział promieniowania ultrafioletowego i podłoże genetyczne. Potencjał kancerogenny blizn pooparzeniowych jest prawdopodobnie wypadkową wszystkich wymienionych czynników [1]. Ryzyko transformacji nowotworowej w obrębie blizn pooparzeniowych nie zostało dokładnie określone. Szacuje się, że wynosi ono $0,7-2 \%$ [2, 3]. Mellemkjaer i wsp. [4] w kohorcie obejmującej ponad 16 tys. osób leczonych z powodu oparzeń w latach 1978-1993 i obserwowanych do 2002 roku nie wykazali wyższej zapadalności na nowotwory skóry. Podobne wyniki uzyskali Lindelöf i wsp. [5]. Wydaje się jednak, że stosunkowo krótki czas obserwacji (odpowiednio 25 i 16 lat) móg1 wpłynąć na wyniki wspomnianych badań. Inne doniesienia wskazują, że okres latencji pomiędzy urazem oparzeniowym a rozwojem nowotworu wynosi średnio 31 lat, przy czym może nawet przekraczać 70 lat $[1,6]$. Wydaje się, że czas ten zależy m.in. od wieku, w którym doszło do urazu termicznego. 
en into account: toxins, co-carcinogens, impaired local blood circulation as well as immune response, and ultraviolet radiation as well as genetic component. Carcinogenic potential of post-burn scars is probably a resultant of all the mentioned factors [1]. The risk for neoplastic transformation within post-burn scars has not been precisely determined. It is estimated at $0.7-2 \%$ [2, 3]. Mellemkjaer et al. [4] in a cohort study involving over 16,000 patients treated due to burns between 1978-1933 and observed till 2002 did not show a higher incidence rate of skin cancers. Similar results were obtained by Lindelöf et al. [5]. However, it seems that relatively short period of observation (25 and 16 years respectively) might have influenced results of the mentioned studies. Other reports indicate that the latency period between a burn injury and development of a neoplasm amounts to 31 years on average, and may even reach 70 years $[1,6]$. The period appears to depend on age at which the thermal trauma occurred, among other factors. Especially long period of latency regards neoplasms that developed due to childhood burns [7]. It is confirmed by the described case, in which a neoplasm developed after more than 60 years since the burn.

Marjolin's tumours occur more often in males, probably due to more common incidence of thermal trauma and more frequent exposure to ultraviolet radiation. These neoplasms are most often found on the skin of lower extremities. Additional, co-carcinogens at these sites may be repeated injuries and circulation disorders secondary to venous insufficiency $[1,7]$. Clinical picture of Marjolin's tumour is diverse - lesions may take the form of infiltration, ulceration or an exophytic tumour [6]. Squamous cell carcinoma is the most common neoplasm that develops within post-burn scars. In the analysis conducted by KowalVern et al. [1], which involved 146 literature items including 412 cases of neoplasms that developed due to post-burn scars, SCC constituted $71 \%$ of cases. Basal cell carcinoma $(12 \%)$, melanoma $(5 \%)$, basosquamous carcinoma (1\%), and sarcomas $(4 \%)$ were less frequently observed. These neoplasms are characterized by aggressive course, higher percentage of local recurrence and metastases as well as mortality as compared with lesions that appeared de novo on the unaffected skin [1]. After the diagnosis is confirmed in histopathological examination, it is necessary to conduct tests for determining the disease advancement.

The authors discovered only a few descriptions of cases reporting a co-existence of two independent and different skin cancers that developed within a postburn scar in international literature [8-12]. Occurrence of tumours with mixed histopathological components seems to be a more common phenomenon - most often
Szczególnie długi był okres latencji w przypadku nowotworów występujących na podłożu oparzeń, do których doszło w dzieciństwie [7]. Również u opisywanego pacjenta do rozwoju nowotworów doszło po ponad 60 latach od oparzenia.

Guzy Marjolina częściej stwierdza się u płci męskiej, prawdopodobnie ze względu na częstsze występowanie urazów termicznych oraz częstszą ekspozycję na promieniowanie ultrafioletowe. Nowotwory te zwykle są umiejscowione na skórze konczyn dolnych. Dodatkowymi kokancerogenami w tej lokalizacji mogą być powtarzane urazy oraz zaburzenia krążenia wtórne do niewydolności żylnej [1, 7]. Obraz kliniczny guza Marjolina jest zróżnicowany - zmiany mogą mieć postać nacieku, owrzodzenia lub egzofitycznego guza [6]. Rak kolczystokomórkowy skóry jest najczęstszym nowotworem, który rozwija się w obrębie blizn pooparzeniowych. Kowal-Vern i wsp. [1] przeanalizowali 146 pozycji piśmiennictwa uwzględniających 412 przypadków nowotworów, które rozwinęły się na podłożu blizn pooparzeniowych. Przypadki SCC stanowiły $71 \%$. Rzadziej stwierdzano raka podstawnokomórkowego $(12 \%)$, czerniaka $(5 \%)$, raka podstawnokolczystokomórkowego (1\%) oraz mięsaki (4\%). Nowotwory te cechują się bardziej agresywnym przebiegiem, wyższym odsetkiem wznów miejscowych i przerzutów oraz śmiertelnością w porównaniu ze zmianami powstałymi de novo na skórze niezmienionej [1]. Po histopatologicznym potwierdzeniu rozpoznania obligatoryjne są badania mające na celu ustalenie stopnia zaawansowania choroby.

Autorzy odnaleźli w piśmiennictwie nieliczne opisy przypadków współistnienia dwóch różnych, niezależnych nowotworów skóry, które rozwinęły się na podłożu blizny pooparzeniowej [8-12]. Wydaje się, że częstszym zjawiskiem jest występowanie guzów o utkaniu mieszanym - zwykle są to rak podstawnokolczystokomórkowy oraz nowotwór złożony z populacji komórek raka kolczystokomórkowego i czerniaka [1]. Pojedyncze doniesienia mówią o występowaniu trzech odrębnych, niezależnych od siebie nowotworów w obrębie blizn pooparzeniowych [13-15].

\section{WNIOSKI}

Przedstawiony przypadek potwierdza istotny potencjał onkogenny blizn pooparzeniowych. Ze względu na umiejscowienie nowotworów nie można wykluczyć roli promieniowania ultrafioletowego jako kokancerogenu. Pacjenci po urazie oparzeniowym powinni być objęci regularną i długoletnią opieką dermatologiczną. 
it is basosquamous carcinoma and a neoplasm consisting in cell population of squamous cell carcinoma and melanoma [1]. Individual reports discuss three separate independent neoplasms within post-burn scars [13-15].

\section{CONCLUSIONS}

The presented case seems to confirm a significant oncogenic potential of post-burn scars. Due to the site of neoplasms, ultraviolet radiation could play the role of a co-carcinogen. Patients who have suffered from thermal trauma should be covered by regular and long-term dermatological care.

\section{KONFLIKT INTERESÓW}

Autorzy nie zgłaszają konfliktu interesów.

\section{CONFLICT OF INTEREST}

The authors declare no conflict of interest.

\section{References}

\section{Piśmiennictwo}

1. Kowal-Vern A., Criswell B.K.: Burn scar neoplasms: a literature review and statistical analysis. Burns 2005, 31, 403-413.

2. Kikuchi H., Nishida T., Kurokawa M., Setoyama M., Kisanuki A.: Three cases of malignant melanoma arising on burn scars. J Dermatol 2003, 30, 617-624.

3. Copcu E.: Marjolin's ulcer: a preventable complication of burns? Plast Reconstr Surg 2009, 124, 156e-164e.

4. Mellemkjaer L., Hölmich L.R., Gridley G., Rabkin C., Olsen J.H.: Risks for skin and other cancers up to 25 years after burn injuries. Epidemiology 2006, 17, 668-673.

5. Lindelöf B., Krynitz B., Granath F., Ekbom A.: Burn injuries and skin cancer: a population-based cohort study. Acta Derm Venereol 2008, 88, 20-22.

6. Das K.K., Chakaraborty A., Rahman A., Khandkar S.: Incidences of malignancy in chronic burn scar ulcers: experience from Bangladesh. Burns 2015, 41, 1315-1321.

7. Saaiq M., Ashraf B.: Marjolin's ulcers in the post-burned lesions and scars. World J Clin Cases 2014, 2, 507-514.

8. Jashnani K.D., Dhume V.M., Bahal N.K.: Epithelioid sarcoma and squamous cell carcinoma arising in a burn scar. Indian J Dermatol 2011, 56, 585-586.

9. Novick M., Gard D.A., Hardy S.B., Spira M.: Burn scar carcinoma: a review and analysis of 46 cases. Trauma 1977, 17, $809-$ 811.

10. Muhlemann M.F., Griffiths R.W., Briggs J.C.: Malignant melanoma and squamous cell carcinoma in a burn scar. Br J Plast Surg 1982, 55, 474-477.

11. Walker A.N., Walker G.K.: Scar-associated malignant melanoma and squamous carcinoma in situ. South Med J 1989, 82, 1419-1421.

12. Ikcda I., Kageshita T., Ono T.: Multiple malignant melanoma and squamous cell carcinoma in a burn scar. Dermatology 1995 , 191, 328-332.

13. Alconchel M.D., Olivares C., Alvarez R.: Squamous cell carcinoma, malignant melanoma and malignant fibrous histiocytoma arising in burn scars. Br J Dermatol 1997, 137, 793-798.

14. Hiscutt E.L., Adams J.R., Ryan J.M., Langtry J.A., Natarajan S.: Atypical fibroxanthoma, lentigo maligna melanoma and squamous cell carcinoma arising in the site of a thermal burn treated with skin grafts. Br J Oral Maxillofac Surg 2009, 47, 157-158.

15. Zuo K.J., Tredget E.E.: Multiple Marjolin's ulcers arising from irradiated post-burn hypertrophic scars: a case report. Burns 2014, 40, e21-5.

Received: 21.03.2019

Accepted: 14.05.2019

Otrzymano: 21.03.2019 r.

Zaakceptowano: 14.05.2019 r.

\section{How to cite this article}

Burdach R., Sławińska M., Biernat W., Nowicki T.K., Jankau J., Kołacz S., Chrzanowska B., Sobjanek M., Starzyńska A.:

Three distinct cutaneous malignancies arising in a post-burn scar. Dermatol Rev/Przegl Dermatol 2019, 106, 417-423.

DOI: https://doi.org/10.5114/dr.2019.88260 